\title{
REGULATORY AND BUSINESS ENVIRONMENTS IN CAMBODIA: CASE STUDIES OF CAMBODIA AND THAILAND SME INVESTORS'
}

\author{
${ }^{1}$ Nisit Panthamit*, 2 Pornchai Wisuttisak \& ${ }^{3}$ Duy Chandina \\ ( First author) \\ ${ }^{1}$ ASEAN research Center, Center of ASEAN Studies, Chiang Mai University \\ ${ }^{1}$ Faculty of Economics, Chiang Mai University \\ ${ }^{2}$ Faculty of Law, Chiang Mai University, Thailand \\ ${ }^{3}$ Department of Finance and Economics, \\ Royal University of Law and Economics, Cambodia \\ (nisitp@gmail.com,nisit.p@cmu.ac.th, pornchai.w@cmu.ac.th, \\ dinaduy@yahoo.com) \\ DOI: https://doi.org/10.22452/jati.vol23no2.4
}

\begin{abstract}
This research paper aims to study challenges over regulatory frameworks and business conditions for Thai SMEs in Cambodia. The paper presents the legal frameworks relating to investment promotion to Cambodia that helps facilitate the increase of foreign and local investment in Cambodia. There are vital challenges for investments in Cambodia, including regulatory and business burdens, corruption by unclear regulations, a lack of policies to support SMEs, culture and preference of Cambodian consumers. The paper provides recommendations for the development of regulations and business environments in Cambodia, including 1) establish stable policies that can specifically support SMEs growth; 2) reform financial support to SMEs to ensure suitability and benefits; and 3) improve the registration system and create a unified registration system for both local SMEs and Thai SMEs.
\end{abstract}

Keywords: SMEs, Regulation, Business condition, Cambodia, Thailand 


\section{Introduction}

The SMEs sector is important to trade and economic development in the ASEAN region. It is believed that SME is crucial for promoting firms' agglomeration and industrialisation, enhance the entrepreneurship, promote innovation, diversify economic growth, and reduce poverty. The SMEs maintain its important role at the early stage until the later stage of development (Ayyagari, Demirgüç-Kunt, \& Beck, 2003). The regulation of business activity has become an important policy concern in both developed and developing countries (European Commission, 2010) Also, in ASEAN, it is believed that SMEs is more flexible than the large enterprises; it is quickly responsive to shocks (Huang, 2003; Tambunan, 2008). SMEs would play significant roles in developing intra trade and cross-border trade in the ASEAN Community. According to the ASEAN 2015 plan, the ASEAN Economic Community (AEC) has become a significant interest in SMEs, as the AEC will be a core initiative for the development of business environments. The AEC would also advance the process of economic integration among the ASEAN members, as well as with countries like Japan, Korea, and China. The integration would then help boost the growth of SMEs' cross-border investments. With regards to the ever-increasing pace of ASEAN integration impacting SMEs, the business environment is critical to enhancing SME participation (OECD, 2017, p. 14). Thus, it is crucial to study the regulatory and business environments that can support or obstruct the SMEs investment in ASEAN member countries. Thus, the scope of this research is on Cambodia's regulatory and business environments which have created challenging opportunities for Thai SMEs willing to do business in Cambodia.

Cambodia's economy has been integrating more closely with the Greater Mekong Subregion and ASEAN region-wide economies. This is due to the fact that the Cambodian government has placed regulations and policies to encourage business investments. However, there exist significant challenges, such as a high degree of business informality leading to a reduction in productivity. The business informality creates uncertainty for engaging in cross-border business and reduces Cambodia's international competitiveness. However, with Cambodia's current development direction, the regulation and business environment have been enhanced.

From Thailand's perspective, Cambodia is a country that has gained international attention in trade and investment. The Thai government has policies to promote trade and investment in neighbouring countries. According to the latest studies by the Department of Trade Promotion, 
Ministry of Commerce, Thailand at the Thai Embassy of Cambodia (20 016 ), Thai products are still popular and trusted by Cambodian consumers. Although the import value from Thailand is down $6.04 \%$ compared to the previous year, Thai goods dominate the market share in Cambodia by more than $50 \%$. Trade between Cambodia and Thailand in 2016 was 5.595 billion dollars, down 0.04 per cent, with imports from Thailand worth 4.65 billion dollars and exports to Thailand: US\$ 936.43 million, up $46.49 \%$.

Imported goods from Thailand include consumer goods, automobile parts and accessories, motor vehicles, motor vehicles and cement. Products that are exported to Thailand are mostly agricultural products, wires and cables, and aluminium.

Table 1: Trade between Thailand -Cambodia 2015-2016

\begin{tabular}{|l|c|c|c|}
\hline & $\mathbf{2 0 1 5}$ & $\mathbf{2 0 1 6}$ & \% change \\
\hline Trade Volume (Million US\$) & $5,597.73$ & $5,595.54$ & -0.04 \\
\hline Export (Million US\$) & 639.26 & 936.4 & 46.49 \\
\hline Import (Million US\$) & $4,958.48$ & $4,659.12$ & -6.04 \\
\hline
\end{tabular}

Source: Department of Trade Promotion,

Ministry of Commerce, Thailand (2016).

With regards to Thai investments in Cambodia, Thai investments have the largest share of security market investments in Cambodia, with an investment share of $96 \%$. For the overall investments in Cambodia, Thailand is in the top ten of the source of investments in Cambodia. This contributed to a close business and investment relationship between Thailand and Cambodia. Thus, Thailand has implemented a policy and regulation which helps facilitate the development of Thai SMEs. It is estimated that the bilateral trade balance between Thailand and Cambodia will increase by 30\% annually. This is due to the expansion of labour markets in Cambodia. Cambodia, as one of the least developed countries, tends to receive various international trade favours from developed countries. Thai investors look at the exports to developed countries, then establish industries and business in Cambodia in order to catch the trade favour from developed countries, which have a large number of import orders.

Large Thai investors and SMEs focus on important and growing businesses of agricultural machinery, construction materials, home furniture, textiles, automobiles, electronics, beauty products, and medical \& healthcare services. These businesses are the main business strength of Thai investors. Within the scope of bilateral trade between Thailand and Cambodia, Thai investments have more impacts toward Cambodia's economy when compared 
to the Cambodian investment in the Thai economy. Both large firms and SMEs from Thailand are looking at the Cambodian markets as a potential profit expansion to keep up with global trade and production.

The development of practices and procedures of Thai SMEs can be a possible framework for building an initiative for SMEs in Cambodia. In addition, the study of Cambodia with regards to regulation and business environments for SMEs can contribute to a better mutual understanding on SMEs' regulation and policy between the two countries. The research would then lead to better policy and regulatory environment, which can assist in the development of SMEs in both countries as well.

This study has the following objectives. First, to investigate the details of regulatory and business environments, which govern small and medium enterprises in Cambodia. Second, to explore how the regulatory and business environments affect or create opportunities for Thai SMEs investment in Cambodia. Third, to propose possible guidance for development on the regulation and business environment in Cambodia and Thailand.

The paper is divided into five parts. The first part introduces the principle and rationale of the study, including literature review and research methodology. The second part provides an overview of the current economic condition of SMEs, as well as the role of Thai SMEs in Cambodia. The third part presents the empirical results of the study. The last part provides the conclusion and recommendation regarding SMEs development in Cambodia.

\section{Literature Review}

In the literature of SMEs, the topic of dimensions and elements of regulatory and business environments are widely discussed. From our searches, we found and grouped the two following categories:

(1) Documents from expert meetings or panel discussions of international organisations; surveys conducted by the International Trade Centre (ITC); and the United Nations Conference on Trade and Development (UNCTAD).

(2) Research publications about SMEs in Cambodia.

UNCTAD (2005) The Commission on Enterprise, Business Facilitation and Development has summarised the meeting to examine how enterprise competitiveness in developing countries and economies in transition could be enhanced through internationalisation, with a focus on outward foreign direct 
investment (OFDI), particularly by small and medium-sized enterprises (SMEs). The meeting also argued The problem is the benefit of OFDI is that it can be an essential mechanism for "South-South cooperation" in addition to its role in strengthening North-South relations. A number of cases discussed at the meeting illustrated the motive and problems from the impact of OFDI on the competitiveness of developing country enterprises in both hosts and home countries include: 1) companies' motives for investing abroad include access to markets, natural resources and strategic assets such as brand names and technology, as well as risk diversification and improving efficiency; 2) bilateral investment guarantee agreements, double taxation avoidance and free-tradearea arrangements have also played a role in encouraging OFDI from developing countries; and 3) developing country SMEs were more likely to be motivated by cost reduction factors and factors related to personal relationships, ethnicity and social connections. Additionally, OFDI by SMEs has a greater tendency to go to neighbouring countries to diversify risk and to access new markets (OECD, 2005). Mounting evidence suggests that trade liberalization and the ability of much of Asia to flexibly respond to world demand - the establishment of intra-regional supply chains since the 1980s and of interregional ones since the late 1990s - is the best explanation for the spectacular growth of South-South trade (World Trade Organization, 2003; Cernat \& Laird, 2003). Moreover, regional integration in ASEAN has encouraged intra-ASEAN investment, which contributed to South-South FDI flows (OECD, 2005, p. 5).

The conclusion of OECD meeting (2017) argued that the business environment is critical to enhance SME participation and benefit from an open and integrated economy. Certain features of the institutional and regulatory framework resulted in disproportionate burdens on SMEs. Inefficient insolvency regimes limit business dynamism, restructuring of viable firms and access to external finance by SMEs (OECD, 2017, p. 14).

Kitching and Smalbone (2010) studied SMEs capacity to manage regulations. They found that the influence of regulations is different for different types of SMEs, which is also in line with the study of Chittenden et al. (2002) that reviewed a variety of reports on the impact of government regulations on small firms in the U.S.A., the U.K., the European Union, Australia and New Zealand. The study found that in all the countries reviewed, governments had accepted that the burden of regulation has a disproportionate impact on small firms. Indeed, SMEs in lower developing countries like Cambodia face a set of complex issues (Kitching \& Smallbone, 2010, p. 4). 
Baily (2008) from the New Zealand Institute of Economic Research or NZIER studied Cambodia Small and Medium Sized Enterprises: Constraints, Policies and Proposals for Their Development. The study found that in 2004 the Cambodian government formed the SMEs Sub-Committee and the SMEs Development Framework. The framework is the first attempt by the government of Cambodia to identify barriers and introduce measures specific to promoting the development of the country's SMEs. Three main barriers for SMEs development were identified: weak regulatory and legal framework; limited SMEs access to finance; and a lack of SMEs support activities. A number of policies have been implemented and recommended to overcome these obstacles to SMEs development. These include policies recommendation to improve the Cambodian business environment and to continue removing the barriers for doing business. The framework that rewards and protects the investment and work of entrepreneurs will increase investment in human and physical capital, and further improve the competitiveness of Cambodian SMEs.

Sothy and Sovatha (2005) found that SMEs sector in Cambodia, wholesale and retail trade played the most significant role in the economy, followed by the manufacturing and accommodation and food services sector, respectively. More interestingly, by deepening the analysis on the manufacturing sector, and employing the average rank of the primary indicators (Number of Entities, Employment and Annual Sales), six potential industries were identified as key potential industries for promoting. Among the six industries, manufacture of food and manufacture of beverages are believed to have high economic potential.

Hatsukano and Tanaka (2014) investigated the bottlenecks for the Cambodian market to connect with the global market. They found that: 1) suitable goods that are manufactured by Cambodian companies do not yet exist because Cambodia imports a wide variety of the required products, including those for daily consumption; 2) SMEs are not yet well enough equipped or developed to provide better quality goods; and 3) barriers to doing businesses in the country remain.

Ung and Sovuthea (2011) studied SMEs access to finance in Cambodia and pointed out that micro-sized firms dominate the private sector in Cambodia. Also, the work indicated that SMEs are important to Cambodia's economic development, especially for building up a strong economic foundation. There was also a high number of SMEs contributing to the economic growth via providing more job opportunities, and facilitation of FDI. However, SMEs are facing challenges in accessing finance, including 
restrictions on the size of loans, high-interest rates and short repayment periods.

Shariff and Peou (2008) researched the relationship between entrepreneurial values, firm financing and management, and the growth performance of small-medium enterprises in Cambodia. The outcomes of hierarchical multiple regression analysis showed that the inclusion of market environment and government policy in the analysis had increased the effect of the relationship between the values of entrepreneurs, firm financing and management, and the growth performance of SMEs in Cambodia. The findings of their study also found that the growth performance of SMEs captures the ability of entrepreneurs to set up and align the company by managing and adapting to the changes within the business and economic environment. Processes will only succeed if adequately skilled and motivated employees are being provided with accurate and timely information. The study confirmed that in SMEs, entrepreneurs who are skilled and adequately trained are able to improve the quality of production and reduce cycle time.

According to the Department of International Trade Promotion report of the Ministry of Commerce (Department of International Trade Promotion, Ministry of Commerce, 2016) in Thailand, the incentive for investors to engage in doing business in Cambodia is favourable. The low wage rate allows operators to produce goods at low production costs and allow foreigners to own their businesses in Cambodia, with no significant limitation in the manufacturing sector. Despite the positive sides, there are still some factors that have limited capacity; one example is that the competition in the market is not taken very seriously. Although the consumers or the population began to earn more, their demand for better things is quite lacking. The Cambodian market attracts both trade and foreign investment. The Cambodian consumers are also foreigners who come to work and tourists who have high purchasing power. Cambodia also allows free movement of capital and investments, which mostly use US dollar as the main currency.

Vathana (2014b) mentioned in their study that challenges facing SMEs in Cambodia are: access to finance; poor business associations; lack of support and facilitation from the government; national and international market expansion; relatively high cost of production compared to that in other ASEAN countries; informality of MSMEs; increased competition; and lack of knowledge on technology adoption. 


\section{Methodology and Objectives}

The research methodology of this study is done by, firstly, utilising documentary research and collecting and analysing government policy, legislation, publication and other documents, with emphasis on material published after 2002 relating to regulatory controls on SMEs in Cambodia and Thailand. Documents were collected from three sources: electronic database available through Chiang Mai University; Google internet search engine; and a manual search of library materials.

Secondly, in-depth interviews were conducted with academicians, government officials, and Thai and Cambodian traders. This was done in order to gather expert information for critical analysis regarding regulatory and business environments for SMEs in Thailand and Cambodia. The experts were chosen from four sectors: government, SMEs, law or consultant firms, and academia. The number of interviewees was nine.

\section{Overview of Cambodia's Economy, Business Environment of Its SMEs}

\section{Overview of the current economic condition of Cambodia}

Cambodia is a fast-growing country in Southeast Asia. According to the World Bank, Cambodia's economic growth rate was at an average of $6.9 \%$ in 20162017 (World Bank, 2017a). The Cambodian economy developed significantly during 1990-2016 with an expansion from US\$ 2.53 billion in 1990 to US\$ 20.2 billion in 2016.

Table 2: Cambodia Economics at a glance

\begin{tabular}{|l|c|c|c|c|}
\hline & $\mathbf{1 9 9 0}$ & $\mathbf{2 0 0 0}$ & $\mathbf{2 0 1 0}$ & $\mathbf{2 0 1 6}$ \\
\hline GDP (current US\$) (billions) & 2.53 & 3.65 & 11.24 & 20.02 \\
\hline GDP growth (annual \%) &.. & 8.8 & 6 & 6.9 \\
\hline Inflation, GDP deflator (annual \%) &.. & -3.2 & 3.1 & 3.5 \\
\hline Agriculture, value added (\% of GDP) & 47 & 38 & 36 & 27 \\
\hline Industry, value added (\% of GDP) & 13 & 23 & 24 & 32 \\
\hline Services, etc., value added (\% of GDP) & 40 & 38 & 40 & 42 \\
\hline Exports of goods and services (\% of GDP) & 16 & 50 & 54 & 61 \\
\hline Imports of goods and services (\% of GDP) & 33 & 62 & 60 & 66 \\
\hline Gross capital formation (\% of GDP) & 12 & 18 & 17 & 23 \\
\hline
\end{tabular}

Sources: World Bank (2017). 
The growth rate is based on factors of expansion of construction activity, an increase in garment exports, the development of agriculture business, and increment of tourist (World Bank, 2017a). The expansion of construction projects further stimulated an inflow of foreign direct investment (FDI) in Cambodia (World Bank, 2016). The FDI based on construction projects rose due to the government policy for Cambodia's exclusive economic zone (SEZ) that supports industrial developments and facilitates export-import businesses in Cambodia (CDC, 2016).

The Cambodia garment and textile sectors rose during 1990-2010, and the sectors remains a vital export-industry for Cambodia (ILO, 2015). The Cambodian government also considers various policies which improve agricultural production through productivity enhancement and increase value-addition of agriculture products (FAO, 2014). While the Cambodian government does not provide direct price support to farmers, it provides VAT exemptions to all agricultural culture products (FAO, 2014). In addition, the Cambodian tourism sector has a very high tourists-to-population ratio. It is estimated that about 4.8 million tourists arrived in Cambodia in 2015 and the trend of tourists arrival is expected to increase (Cambodia Government, 2016). What can be seen is that Cambodia is at the important step toward economic development under government support.

Table 3: Economic forecasts for Southeast Asian Country

\begin{tabular}{|l|c|c|}
\hline \multicolumn{1}{|c|}{ Country } & $\mathbf{2 0 1 7}$ & $\mathbf{2 0 1 8}$ \\
\hline Brunei Darussalam & 1.0 & 2.5 \\
\hline Cambodia & 7.1 & 7.1 \\
\hline Indonesia & 5.1 & 5.3 \\
\hline Lao People's Dem. Rep. & 6.9 & 7.0 \\
\hline Malaysia & 4.4 & 4.6 \\
\hline Myanmar & 7.7 & 8.0 \\
\hline Philippines & 6.4 & 6.6 \\
\hline Singapore & 2.2 & 2.3 \\
\hline Thailand & 3.5 & 3.6 \\
\hline Viet Nam & 6.5 & 6.7 \\
\hline
\end{tabular}

Source: “Asian Development Outlook 2017" (2017).

The support on economic development also continues, based on Cambodia Industrial Development Policy 2015 - 2025 which has a principal purpose to build the "Market Orientation and Enabling Environment for Industrial Development". The policy also links the Cambodian economic 
development with the regional liberalisation frameworks of ASEAN. ADB forecasts that Cambodia's GDP will be ranked second at the top of ASEAN countries in 2017 and 2018. The economic development along with the government policy on market orientation and liberalisation has benefited SMEs in Cambodia. SMEs in Cambodia are mainly based on very small business or micro-business; $97 \%$ of the 505,134 firms in Cambodia are micro businesses (Thangavelu, Oum, \& Neak, 2017). The small businesses account for $2 \%$ of the share (see Table 3 ).

The share of medium-sized and large firms is low, accounting for only $0.16 \%$ and $0.15 \%$ of total firms in Cambodia's economy (Thangavelu et al., 2017). Thus, industry, trade and service sectors in Cambodia are mainly based on micro and small businesses. The small businesses have become a backbone for economic development in Cambodia.

Table 4: SMEs in Cambodia

\begin{tabular}{|l|c|c|c|c|c|}
\hline & $\begin{array}{c}\text { Total/ } \\
\text { average }\end{array}$ & $\begin{array}{c}\text { Micro } \\
\mathbf{( 1 - 1 0 )}\end{array}$ & $\begin{array}{c}\text { Small } \\
\mathbf{( 1 1 - 5 0 )}\end{array}$ & $\begin{array}{c}\text { Medium } \\
\mathbf{( 5 1 - 1 0 0 )}\end{array}$ & $\begin{array}{c}\text { Large } \\
\text { (over 100) }\end{array}$ \\
\hline \# of enterprises & 505,134 & 493,544 & 10,009 & 800 & 781 \\
\hline \% share of total & 100.0 & 97.7 & 2.0 & 0.2 & 0.1 \\
\hline \# of persons engaged & $1,673,390$ & 975,980 & 191,792 & 53,879 & 451,739 \\
\hline \% share of total & 100.0 & 58.3 & 11.5 & 3.2 & 27.0 \\
\hline $\begin{array}{l}\text { Total sales (million } \\
\text { USD/month) }\end{array}$ & 293 & 147 & 53.2 & 10 & 82.8 \\
\hline \% share of total & 100.0 & 50.2 & 18.2 & 3.4 & 28.3 \\
\hline
\end{tabular}

Source: Vathana (2014a, p. 3)

According to the establishment of SME Sub-Committee by resolution No. 45 S.S.R on August 28, 2007, under the Minister of Industry, Mines and Energy (MIME), SMEs is defined according to full-time employees (Polsaram, Kulsiri, Techasermsukkul, Htwe, \& Kwanchainond, 2011). In the case that the employee number is not an appropriate indicator for detection, the size of total assets or a combination of the employees and asset will be an indicator of SMEs definition. Based on the definition indicators, businesses in Cambodia can be classified into four categories: micro business, small business, medium business and large business (Polsaram et al., 2011). 
Table 5: Businesses categories in Cambodia

\begin{tabular}{|l|c|c|}
\hline & Statistical Employee number & Financial Assets excludingland (USD) \\
\hline Micro & Less than 10 & Less than 50,000 \\
\hline Small & $11-50$ & $50,000-250,000$ \\
\hline Medium & $51-100$ & $250,000-500,000$ \\
\hline Large & Over 100 & Over 500,000 \\
\hline
\end{tabular}

Source: Polsaram et al. (2011, p. 3-2).

The micro and small businesses are firms having 11-50 employees and a financial asset that is not more than U\$250,000. For this study, the definition of SMEs refers to any businesses with up to 100 employees.

\section{Regulatory and business environments for SMES}

SMEs in Cambodia continue to grow rapidly in size and number of operations. The SMEs growth is supported by favourable business, regulatory and policy environments. According to the World Bank report on "Doing Business 2017: Equal Opportunity for All", Cambodia has continued to improve its business environment over the past year (World Bank, 2017b). The Cambodian government focuses on building up a liberal market regime under a proinvestor legal and policy framework (U.S. Department of State, 2015).

Table 6: Advantage to business and investment in Cambodia

\begin{tabular}{|l|l|}
\hline Openness to foreign investment & $\begin{array}{l}\text { Favourable investment incentive and tax } \\
\text { regime }\end{array}$ \\
\hline Business-friendly government & Abundant natural resources \\
\hline Foreign-friendly population & World class tourist cites \\
\hline Low levels of government red tape & Low cost, young, and energetic workforce \\
\hline $\begin{array}{l}\text { Widespread use and acceptance of } \\
\text { US dollar }\end{array}$ & $\begin{array}{l}\text { Easy access to larger economies nearby } \\
\text { Thailand, Vietnam, and China }\end{array}$ \\
\hline
\end{tabular}

Source: DFDL (2013)

The government also provided an incentive for foreign investors by granting 100\% foreign ownership of companies, corporate tax exemption up to eight years, duty-free import of capital goods, and no restrictions on capital repatriation (U.S. Department of State, 2015). With the increase in investment in the Cambodian market, the business environment tends to be more marketoriented, with less regulatory and business barriers. The improvement of market orientation in Cambodia has led to a healthy business environment. 
The increase of investment in Cambodia market facilitates SMEs development by SMEs investments in various economic sectors in Cambodia. In addition, based on the Cambodia Industrial Development Policy, the government plans to support SMEs by (Cambodia Government, 2015):

- Encourage the preparation of medium-term plan to nurture the growth of SMEs by way of identifying enterprises with good export potentials, developing new products, linking to multinational corporations (MNCs), connecting them to the value chain and regional production networks, and preparing concrete action framework to develop them.

- Strengthen the SME development framework and mechanism, focusing on the preparation of registration, monitoring and tracking the progress of this sector. The objective is to encourage Cambodian enterprises to register in the formal tax regime, thus allowing the Royal Government to have accurate information about the sector so that it can initiate proper supporting policies to enable better access to credit information and another business advises growing their business and investment.

- Strengthen the single-window mechanism for registering SMEs by way of using their registration and account ledgers as the basis for evaluating and determining criteria for providing incentives and receiving support from the Royal Government.

Article 56 of the Cambodian Constitution 1993 stipulates that Cambodia must implement a market economy system. Also, Article 61 of the Constitution obligates the government to promote economic development in all sectors, especially in agriculture, handicrafts, and industries. Furthermore, the SMEs in Cambodia have significant support from a law reform in 2005. The National Assembly adopted the Law on Commercial Enterprises on April 26, 2005, which took effect on May 19, 2005 (CDC, 2017). The Law on Commercial Enterprises has become the primary and comprehensive enterprise law in Cambodia. This law governs the partnership entity, limited company, and public limited company. The law covers both local and foreign businesses. The Law on Commercial Enterprises is considered as a modernisation of the regulatory framework for business enterprises. The law contributes to the development of commercial regulation and registration. Trading and services businesses are under commercial regulation and registration (CDC, 2017). The regulation and registration become legal tools to standardise all business 
entities in Cambodia. Thus, the government policy and regulatory framework in Cambodia are set up to ensure SMEs development under an open and liberalised economy. Thus, the regulation and business environment for SMEs in Cambodia influences SMEs development directly by mandating or prohibiting behaviour of business (or firms), as well as indirectly by shaping the behaviour of other stakeholders with whom firms interact with actual and prospective competitors, suppliers, employees, infrastructure providers, and regulatory authorities (see Kitching \& Smallbone, 2010, pp. 4-5 for more details).

\section{Economic Environment of SMEs in Cambodia}

SMEs investment in Cambodia tends to increase as there is an influx of foreign investment in Cambodia. Since the recovery from the civil war back in the 1990s, the country has liberalised its international trades which amounted to a high attractiveness for business ventures. The high steady economic growth during the 2000s to 2018 has led Cambodia's economy to become an attractive location for investors. In addition, the Cambodian government also set up various legal and policy mechanisms which provide more favourability for making foreign investments. From our study, the Cambodian government provides support for investment by:

\section{- Enactment of Cambodian Law on Investment (LOI)}

The Cambodian Law on Investment encourages both local and foreign investors without discrimination and provides an incentive (especially on the import duty and tax on profit, up to 9 years maximum). By law, the export industry is given priority from the Cambodian government.

\section{- Establishment of the special economic zone}

The established Special Economic Zone (SEZ) helps stimulated the decision for international investors to do business and industries in the SEZ. The SEZ facilitates industries and businesses that are aiming to build local production for local and international trades.

- Favourable taxes and labour law

The Cambodia government provides tax frameworks which help in easing investment and administrating the business. Customs taxes are exempted for some investment types relating to imports and exports in Cambodia. Tax-free periods are also provided for some businesses. The labour law has also been strengthened to make 
clear legal protection to labour while balancing the policies with the business owners to keep them satisfied.

Thus, the above legal frameworks relating to investment promotion to Cambodia has helped facilitate an increase of foreign and local investments in Cambodia.

\section{Findings}

The business environment of a successful business of SMEs in Cambodia

From the study we found that the necessities for building up a successful business of SMEs in Cambodia are the following:

\section{Preparation to changes in business}

SMEs in Cambodia have to face various changes in market condition. To survive in the market, SMEs should have a backup plan to adapt their business according to the unexpected circumstances. The Cambodian market economy is constantly changing. Changing the strategic plans at any time is important. If there are business changes, especially in a family business, it is vital that SMEs have to restart their way of business.

An example is during a political election where the prices of goods are high, but after the election, the prices go down. SMEs then have to keep up with the changes of markets. Thus, the SMEs investments in Cambodia must understand the real need of Cambodian customers and have a clear goal of business that can change according to the conditions (interview with a Cambodian retail manager). This is in accordance with the theoretical framework mentioned by Kitching and Smalborne (2010).

\section{Seeking good business alliance or partners}

Adapting to the situation and having a backup plan are factors to be successful in doing business in Cambodia. However, it is important to understand that the Cambodians have ways of doing their businesses. SMEs, especially foreign investments, must have good connections and alliances. Knowing people is a must for businesses to survive in Cambodia. SMEs must know the surrounding society, culture, lifestyle, income, and needs of the people. SMEs then have to seek alliances or partners who can help move and facilitate their businesses. The connections and relationships with alliances and partners are 
significant for making an effective response from consumers in Cambodia, which is in line with the study done by Kaewkumkong (2012).

\section{SMEs human resource management}

Human resource management is a difficult task for businesses in Cambodia, where there is a lack of skilled professionals. According to interviews with local and Thai investors in Cambodia, it was noted that while aiming to offer good products or services to customers, SMEs also have to recruit and retain good staff members. Since the Cambodian economy has just been revived after the civil war, the training and education system still cannot provide the human resources needed for participating in high-performance businesses. SMEs have to make sure that they can recruit and retain staff members who can help run their businesses. For example, one interviewee mentioned about a Thai restaurant that opened in Phnom Penh with many customers. However, the owners of the restaurant were faced with the difficulty of maintaining their cooks and chefs, as they seemed to work short term and then move on. Also, the restaurant could not find enough waiters and waitresses who were skilled in hospitality and services. Even though the owners of the restaurant offered high salaries, they could not find enough chefs.

Another example is from the medical business, where Bangkok Hospital was opened in Cambodia but faced difficulties in finding doctors and medical staffs to work in the hospital. Meanwhile, Thai and Cambodian agencies made a profit by transporting Cambodian patients to Thailand to receive medical treatment, as Thailand offered better services. Thus, the lack of an efficient labour force is a major issue for SMEs or large firms based in Cambodia, and it affects productivity.

\section{Know the tastes of customers}

It is time-consuming to know the tastes of Cambodian customers, however knowing very little about the customers' tastes can devastatingly ruin the SMEs businesses. Upon starting a business, SMEs must know their customers. If you know the customers' tastes, the customer will come back again and again. In the experience of running a business, the owners must be involved with the customers, know their basic needs and their economic conditions. For instance, people who have lesser income would prefer to buy cosmetic products at a reasonable and affordable price. It is a must that business owners see the market and talk to customers to determine how one can gradually move their business according to their customers' preferences. Cambodian customers need to have that trust when purchasing an item or acquiring a 
service. So when they are deciding to buy some products, the business owner of the product should show that he/she also uses that product. One investor interviewee gave an example whereby the Thai trader (interview with $\mathrm{Mr} \mathrm{B}$ and Mrs B) initiated the sale of toothpaste products in Cambodia. They started by importing toothpaste products from Thailand and sold them to Cambodian customers who liked to try the Thai products. Afterwards, the customers would come back with their friends to buy more products. From that point, $\mathrm{Mr}$ B and Mrs B developed various cosmetic products that satisfied the needs of their Cambodian customers. Thus, Cambodian's preference for Thai products implies a lacking of customer loyalty towards local, Cambodian brands.

\section{Understanding the environment of business}

Apart from knowing the customers' needs, SMEs must know the Cambodian market and how to build up the market. This includes employing marketing techniques to increase product awareness, such as giving out samples or trial products to potential customers. Also, marketing through media such as radio advertisement is important. Radio advertisement still works in Cambodia as the market outside the city still relies on the radio for information. Customers still listen to the radio and choose products that they have been informed about. In the provinces of Cambodia, there are no shops. Therefore the sales should be directed to the customers. However, at the current stage, even if they have many orders from a wide range of customers, there still lacks a staff team to sell the products in the provinces of Cambodia.

\section{Start your way of business}

To open a new market in Cambodia, it is important that you build yourown brand and products which suit the customer's needs. While it is easy to buy brand products and resell them, it is more profitable to build your brand and sell them to the customers. Thus, the tip of doing your business in Cambodia successfully is to start yourown products and brands. Once the Cambodian customers accept the products and brands, your business will run at a high profit rather than just being traders who resell brand products.

\section{Obstacles of the business condition in Cambodia}

\section{Regulatory and business burdens}

It is difficult for foreign investors to directly deal with government agencies given unclear regulations of business registration and taxes. Foreign SMEs are faced with due processes and legal obstacles to set up and operate their 
businesses. Also, with a shortage of infrastructure development, it is not so easy for businesses to use the logistics system in Cambodia. Moreover, foreign businesses also face the difficulty of transferring money in and out of Cambodia. Cambodian markets still rely on cash as a means for businesses and trades. Foreign investors have to send money by using money transferring services which are safer and more reliable than relying on the banking systems in Cambodia.

\section{Corruption by unclear regulations}

As there are unclear regulations and tax systems, government officers tend to request bribes before permitting businesses to operate in Cambodia. Even if SMEs would like to make a legal registration, they would have to facilitate the process by paying some money to officers. Alternatively, SMEs must have connections with officers in order to speed up the registration approval. With a lack of clear communication in the tax system, both local and foreign SMEs have to pay a sum of money to tax officers in order to clear tax requirements annually. This payment tends to be a bribe for tax officers.

\section{Lack of policy support for SMEs}

The Cambodian government, while showing that it has fully supported the SMEs, it lacks a solid policy to support SMEs. SMEs have to survive on their means with no help or support from the government. Small traders and SMEs do not have the financial and knowledge support from the government. This may contribute to many obstacles for SMEs to start up their businesses and to achieve their business objectives.

\section{Culture and preference of Cambodian consumers}

The Cambodian culture is made up of different political regimes, local and central perspectives, and old and new generations. To be successful in business, it is essential to understand the customers' preferences and behaviours. Also, the old and new generation in Cambodia's economy implement different styles of business management, where the new generation adopts the new style of business while the old generation tends to be slow in changing to the new style. 


\section{Research Analysis}

\section{Recommendation to Cambodian government's policy and support to SMEs Government law and policy providing specific support to SMEs}

It is important that the Cambodian government establish a solid policy and an implementation that can especially support SMEs growth. An example would be the adoption of SMEs promotion law and policy, which can be vital within the government mechanism for promoting SMEs. The example is from Malaysia and Thailand, whereby the specific law and policy enabled both governments to support SMEs directly. In the case of Malaysia, the Malaysian government set up the SMEs promotion policy by establishing the SME Corporation Malaysia (SME Corp. Malaysia) as the Agency under the Ministry of International Trade and Industry Malaysia (SME Corp. Malaysia, 2017). The SME Corp. Malaysia has an important duty, which is to formulate the overall policies and strategies for SMEs and to coordinate the implementation of SMEs development programs across all business sectors (SME Corp. Malaysia, 2017). In Thailand case, the SMEs Promotion Act, B.E. 2543 (2000) has been adopted to institute the SMEs Promotion Commission and the office of SMEs Promotion Commission. The commission and office are the acting cohort agency for setting up regulations and policies to support SMEs in Thailand. Based on the work of SMEs promotion by the regulation of SMEs Promotion Act, the SMEs in Thailand have expanded and improved rapidly. Thus, it is recommended that the Cambodian government should have in place a specific law and policy that provides full support for SMEs to reach its growth potential. This suggestion is also in line with the study by Shirley V. Ramesh (2017) who examined the ASEAN Single Market policies and strategies whilst making a comparative study with the similar efforts carried out in the European Union (EU). They found that ASEAN mirrored the single market aspirations against its diverse geopolitical backdrop, resulting in the launch of a single market that is unique to the region.

\section{Financial suitability and support to SMEs}

There should also be development and reform on the financial sector that ensures a benefit for SMEs. As mentioned, SMEs primarily rely on cash investments. Therefore financial suitability should be adopted in order to promote SMEs in Cambodia. For instance, Thailand has established the Thai SMEs bank which specifically supports SMEs finances (SMEs Bank of Thailand, 2017). SMEs can rely on financial assistance and products from the Thai SMEs banks. These banks become a key financial supporter of SMEs 
expansion and developments in all business sectors (SMEs Bank of Thailand, 2017). Thus, there should be an establishment of a financial institution that can provide specific help to SMEs in Cambodia. The institution should also think about financial products that serve the direct SMEs' financial needs in Cambodia. The financial institution should make sure that it can serve the increase of SMEs' cash investment and expansion in Cambodia.

\section{Clearer regulation for SMEs}

Any unclear regulation and legal burdens to SMEs in Cambodia should be reformed and streamlined (Baily, 2008). The registration system, whether the national or provincial system, should be harmonised to create a unified registration system for SMEs. The unified registration system would provide a clearer regulatory framework for SMEs, as well as tackle corruption problems. It should be noted here that political power in Cambodia is still a double movement (Lim, 2013) by 1) deploying their control over economic resources, including foreign aid, into strengthening their patron-client networks; and 2) translating their control over patron-client relations into centralisation and control over the state. Thus, officers with authoritative power that may hamper SMEs business should be scrutinised and reformed. For instance, any authoritative exercise from officers towards SMEs should be checked. SMEs should be able to request for a clearer explanation, as well as able to appeal the officers' decision. Thus, the reform and removal of an unclear regulation would create business confidence for SMEs in Cambodia.

\section{Recommendation for Thai SMEs to succeed in Cambodia's market}

\section{Networks with local and foreign businesses}

In doing business or making investments in Cambodia, connections with the locals is a must. The local person or business can help facilitate the establishment of the business, trade and operation. It is possible for Thai SMEs to do joint businesses with trusted local Cambodian business partners. Overall Cambodians are happy to do business with Thai SMEs. This is because Thailand and Cambodia are closely linked in border trades and investments. However, there are some cases of difficulty to have a joint venture between Thai and Cambodian investment in the Cambodian markets. The business pain gets heavier when one knows that it is more difficult for Thai SMEs to start their investment or trade in Cambodia without having any local connections in Cambodia. Also, Thai SMEs in Cambodia should be associated with Thai business centres or associations. There is a prominent Thai Chamber of 
Commerce in Phnom Penh. The chamber can be a reliable consultation centre for Thai SMEs. The new Thai investor can ask for knowledge from experienced Thai investors in Cambodia.

\section{Prepare for uncertainty in regulatory and business environments}

Doing business in Cambodia with unclear legal requirements can lead Thai SMEs to an unclear position. It is important that the SMEs prepare themselves to cope with such obstacles, both from the authorities and local competitors. Thai SMEs would have to change their attitude of doing business in Cambodia. New businesses in Cambodia are always faced with uncertainty, but if they survive their business will achieve successful profits as the Cambodian economy is growing at a fast rate.

\section{Looking at the positive side}

Most experienced Thai entrepreneurs in Cambodia point out that the Cambodians prefer to buy Thai products and there are demands for many more goods from Thailand. The Thai SMEs may start as a trading business which sells products from Thailand. Once the trades have been settled, the next move is to set up an industrial sector in Cambodia to satisfy the high demands of Cambodian consumers.

\section{Conclusion}

There is a bright future for SMEs in Cambodia. Thai and Cambodian SMEs are at a significant period of economic development in Cambodia. SMEs are able to expand their businesses with the rise of demand from Cambodian consumers. Also, with its openness to international trade, Cambodia is a significant market for an industry with an export-led plan. However, there exist some major challenges that are entrenched within the regulatory and business environment of Cambodia. Thus, when considering SMEs operation in Cambodia, gaining an in-depth insight would provide a better understanding of the obstacles SMEs faced to moving forward in the future.

\section{References}

Asian Development Outlook 2017. (2017). Asian Development Bank's website. Retrieved from https://www.adb.org/countries/cambodia/economy 
Ayyagari, M., Beck, T., \& Demirgüç-Kunt, A. (2003). Small and Medium Enterprises across the Globe: A New Database. Policy Research Working Paper, No. 3127. World Bank, Washington, DC: World Bank. Retrieved from

https://openknowledge.worldbank.org/handle/10986/18131

Baily, P. (2008). Cambodia Small and Medium-Sized: Enterprises: Constraints, Policies and Proposals for Their Development. In H. Lim (Ed.), SME in Asia and Globalization (pp. 1-36). Jakarta: ERIA.

Cambodia Government. (2015). Cambodia Industrial Development Policy 2015 2025. Retrieved from

http://www.cambodiainvestment.gov.kh/content/uploads/2015/09/IDP -English-Version-FINAL1.pdf

Cambodia Government. (2016). Cambodia Macroeconomic Monitor- Mid Year Assesment 2016. Retrieved from

http://www.mef.gov.kh/documents/shares/CMM_Mid-2016-

Assessment-English-Version.pdf

Cambodia Trade and Investment Guidebook. (2017). n.p: Council for the Development of Cambodia.

CDC. (2016). Policies toward FDI. Retrieved from http://www.cambodiainvestment.gov.kh/investment-scheme/policiestoward-fdi.html

CDC. (2017). Company-Regulatory Framework for the Commercial Enterprise.

Retrieved from http://www.cambodiainvestment.gov.kh/investorsinformation/company.html

Cernat, L., \& Laird, S.(2003). North, south, east, west: what's best? Modern RTA's and their implications for the stability of trade policy. Centre for Research in Economic Development and International Trade (CREDIT) Paper No. 03/11, University of Nottingham. Retrieved from http://papers.ssrn.com/sol3/papers.cfm?abstract_id $=456941$

Department of International Trade Promotion, Ministry of Commerce, Thailand. (2016). Kingdom of Thailand [in the Thai language]. Bangkok: Thai Trade and Business Development Center, Department of Trade Promotion, Ministry of Commerce.

DFDL. (2013). Legal, Tax and Investment Guide-Cambodia. Phnom Penh: DFDL.

FAO. (2014). Country Fact Sheet on Food and Agriculture Policy Trends. Retrieved from http://www.fao.org/docrep/field/009/i3761e/i3761e.pdf

Hatsukano, N., \& Tanaka, K. (2014). Challenges to Make Cambodian SMEs Participate in Global Value Chains: Toward Addressing Poverty and Inequality. BRC Research Report. Retrieved from 
http://www.ide.go.jp/library/English/Publish/Download/Brc/pdf/14_03 .pdf

ILO. (2015). Growth continues for Cambodia's garment and footwear sector. Cambodia Garment and Footwear Sector Bulletin, 1.

Kitching, J., \& Smallbone, D. (2010). Literature review for the SME Capability to Manage Regulation project. Retrieved from http://eprints.kingston.ac.uk/12064/1/Kitching-J-12064.pdf

Kaewkumkong, A. (2012). Opportunities and Market Channels of Thai SME in Cambodia, Journal of Mekong Societies, 8(1), 95-113.

Lim, A. C.-H. (2013). Cambodia Rising: Neoliberal Violence and Development. JATI - Journal of Southeast Asian Studies, [S.1.], v. 18, p. 6172, Aug. 2017.

Ministry of Industry and Handicraft, Kingdom of Cambodia. (2015). Kingdom

of Cambodia Project for Strengthening of Mall And Medium Enterprise [SME] Support System: Final Report. Tokyo: Japan International Cooperation Agency.

OECD. (2017). Enhancing the Contributions of SMEs in a Global and Digitalised Economy. Meeting of the OECD Council at Ministerial Level Paris, 7-8 June 2017. Retrieved from https://www.oecd.org/mcm/documents/C-MIN-2017-8-EN.pdf

Polsaram, P., Kulsiri, P., Techasermsukkul, L., Htwe, T. D., \& Kwanchainond, K. (2011). A Survey Research Project on "Small and Medium Enterprises Development Policies of 4 ASEAN Countries": Brunei Darussalam, Cambodia, Lao PDR, Myanmar. ASEAN's website. Retrieved from https://www.asean.org/wpcontent/uploads/images/documents/SME\%20Policies\%20in \%204\%20A SEAN\%20Countries\%20-\%20Brunei\%20Darussalam.pdf

Ramesh, S. V. (2017). The ASEAN Single Market: A Comparative Study. JATI Journal of Southeast Asian Studies, 22(1), 9-25.

Shariff, M. N. M., \& Peou, C. (2008). The relationship of entrepreneurial values, firm financing and the management and growth performance of smallmedium enterprises in Cambodia. Problems and Perspectives in Management, 6(4), 2008.

SME Corp. Malaysia. (2017). About SME Corp. Malaysia. Retrieved from http://www.smecorp.gov.my/index.php/en/about/2015-12-21-08-4911/about-sme-corp-malaysia

SMEs Bank of Thailand. (2017). About SMEs Bank of Thailand- Background. Retrieved from https://www.smebank.co.th/En/About 
Sothy, E., \& Sovatha, S. (2005). Promoting Employment through identifying SME exportable market: A Shift-share Approach. https://cdri.org.kh/wp-content/uploads/MERN-Small-grant-2Cambodia.pdf

Thangavelu, S. M., Oum, S., \& Neak, S. (2017). SME Participation in ASEAN and East Asian Integration: The Case of Cambodia. Journal of Southeast Asian Economies, 34(1), 175-192.

UNCTAD. (2005). United Nations Conference on Trade and Development. Retrieved from https://unctad.org/en/Docs/c3em26d2a5_en.pdf

U.S. Department of State. (2015). Cambodia Investment Climate Statement. Retrieved from https://www.state.gov/documents/organization/241718.pdf

Ung, L., \& Sovuthea, H. (2011). SMEs Access to Finance in Cambodia. In Harvie, Charles; Sothea Oum and Dionisuis Narjoko (eds.), Small and Medium Enterprises (SMEs) Access to Finance in Selected East Asian Economies. ERIA Research Project Report 2010- 14, Jakarta: ERIA. pp.83-116.

Vathana, R. (2014a). Are We Ready? Cambodia's in the Context of AEC 2015. Paper presented at the National Conference on Integration of ASEAN Economic Community 2015 Challenges and Opportunities for SME sector in Cambodia, Phnom Penh Water Supply Authority, Phnom Penh, 16-17 December. Retrieved from http://www.mih.gov.kh/File/UploadedFiles/1_19_2015_7_3_21_10\%20 Roth\%20Vathan\%20CDRI_en.pdf

Vathana, R. (2014b). Understanding SME Policy Environment in ASEAN. Development Research Forum Policy Brief No.7. Phnom Penh: CDRI.

World Bank. (2016). Cambodia Economic Update- Enhancing Export Competitiveness: The Key to Cambodia's Future Economic Success. Phnom Penh: The World Bank. Retrieved from http://gs.mef.gov.kh/contents/uploads/2016/10/October-2016Cambodia-Economic-Update-Oct-10-2016-final.pdf

World Bank. (2017a). Cambodia Economic Update April 2017: Staying Competitive through Improving Productivity. Retrieved from http://www.worldbank.org/en/country/cambodia/publication/cambodi a-economic-update-april-2017

World Bank. (2017b). Cambodia Improves Business Environment in 2017. Retrieved from http://www.worldbank.org/en/news/pressrelease/2016/10/26/cambodia-improves-business-environment-in-2017 
World Trade Organization. (2003). I.B.1, Selected features of South-South trade developments in the 1990- 2001 period. Geneva: World Trade Organization, 2004. Retrieved from http://www.wto.org/english/res_e/booksp_e/anrep_e/world_trade_rep ort_2003_e.pdf Zebregs, H. Intraregional trade in emerging Asia. IMF Policy Discussion Paper No. 04/01

\section{Appendix: List of Interviewees}

\begin{tabular}{|l|l|l|l|}
\hline Bil & Interviewee & \multicolumn{1}{|c|}{ Position and designation } & Interview period \\
\hline 1 & Mrs A & $\begin{array}{l}\text { Thai Government officer in } \\
\text { Cambodia }\end{array}$ & $\begin{array}{l}\text { May, October and } \\
\text { November 2016 }\end{array}$ \\
\hline 2 & Mr and Mrs B & $\begin{array}{l}\text { Thai owner of OEM cosmetics and } \\
\text { beauty products from Thailand }\end{array}$ & November 2016 \\
\hline 3 & Mr C & $\begin{array}{l}\text { Thai owner of the cloth hanger } \\
\text { factory }\end{array}$ & November 2016 \\
\hline 4 & Ms D & $\begin{array}{l}\text { Thai owner of fresh flower business } \\
\text { and Flower arrangement }\end{array}$ & November 2016 \\
\hline 5 & Mr E & $\begin{array}{l}\text { Cambodian Managers of all kinds of } \\
\text { beverages }\end{array}$ & Novembers 2016 \\
\hline 6 & Mr F & $\begin{array}{l}\text { Cambodian businessman- Beer } \\
\text { distributors, Fried Rice franchise and } \\
\text { lecturer in University }\end{array}$ & November 2016 \\
\hline 7 & Mr G and Mr H & $\begin{array}{l}\text { Legal experts from DFDL } \\
\text { and }\end{array}$ \\
\hline
\end{tabular}

